\title{
Genetic history and stock identity of beluga whales in Kotzebue Sound
}

\author{
Gregory O'Corry-Crowe1, Tatiana Ferrer ${ }^{1}$, John J. Citta ${ }^{2}$, Robert Suydam ${ }^{3}$, Lori Quakenbush², John J. Burns ${ }^{4}$, \\ Jorge Monroy ${ }^{1}$, Alex Whiting ${ }^{5}$, Glenn Seaman ${ }^{6}$, Willie Goodwin, Sr. ${ }^{7}$, Matthias Meyer ${ }^{8}$, Sarah Rodgers ${ }^{1}$ \& \\ Kathryn J. Frost ${ }^{9}$
}

\author{
${ }^{1}$ Harbor Branch Oceanographic Institute, Florida Atlantic University, Fort Pierce, FL, USA \\ ${ }^{2}$ Alaska Department of Fish and Game, Fairbanks, AK, USA \\ ${ }^{3}$ North Slope Borough Department of Wildlife Management, Utqiagivik, AK, USA \\ ${ }^{4}$ Living Resources Inc., Fairbanks, AK, USA \\ ${ }^{5}$ Native Village of Kotzebue, Kotzebue, AK, USA \\ ${ }^{6}$ Seaman Consulting, Homer, AK, USA \\ ${ }^{7}$ Alaska Beluga Whale Committee, Kotzebue, AK, USA \\ ${ }^{8}$ Max Planck Institute for Evolutionary Anthropology, Leipzig, Germany \\ ${ }^{9}$ Alaska Beluga Whale Committee, Kailua-Kona, HI, USA
}

\begin{abstract}
We investigate the recent history and stock identity of beluga whales (Delphinapterus leucas) in Kotzebue Sound in the Chukchi Sea, a region long frequented by large numbers of belugas in summer until their near disappearance in the 1980s. Wide variation in numbers since then suggests a complex recent history that hinders recovery efforts. Analysis of teeth sampled during the historical (pre-decline) era using ancient DNA (aDNA) methods found that the original Kotzebue Sound whales were differentiated for mitochondrial DNA (mtDNA) from other summering concentrations across the Pacific Arctic revealing a demographically distinct subpopulation where long-established migratory culture likely facilitated population divergence. Analysis of microsatellite (nDNA) and mtDNA markers in belugas from the contemporary (post-decline) era revealed that whales from other stocks likely visited Kotzebue Sound, including during two low ice years when relatively large numbers of whales were present. Some mtDNA lineages were found only in Kotzebue Sound, with one recorded in both the historical and contemporary eras. Exclusion tests found a number of whales in Kotzebue Sound during the contemporary era that had nDNA genotypes unlikely to arise in other contemporary stocks in the Pacific Arctic. Our findings indicate that the Kotzebue Sound belugas comprised a unique stock of which a few remnants likely still co-occur with belugas from other larger stocks. We recommend that the US government work through the co-management process to greatly reduce or eliminate the taking of belugas, especially adult females, likely to belong to the Kotzebue Sound stock, until they recover.
\end{abstract}

This article is part of the special cluster Beluga whales (Delphinapterus leucas): knowledge from the wild, human care and TEK, which has been funded by Mystic Aquarium, CAFF and the Norwegian Ministry of Climate and Environment.

\section{Keywords}

population decline; ancient DNA Delphinapterus leucas; Indigenous Knowledge; Iñupiat; migratory culture

\section{Correspondence}

Gregory O'Corry-Crowe, Harbor Branch Oceanographic Institute, Florida Atlantic University, 5600 US 1 North, Fort Pierce, FL 34946, USA. E-mail gocorryc@fau.edu

\author{
Abbreviations \\ ABWC: Alaska Beluga Whale Committee \\ aDNA: ancient DNA \\ bp: base pair \\ IK: Indigenous Knowledge \\ MMPA: US Marine Mammal Protection Act \\ (1972; US Public Law 92-522) \\ mtDNA: mitochondrial DNA \\ nDNA: microsatellite DNA \\ NGS: next generation sequencing \\ SNP: single nucleotide polymorphism
}

\section{Introduction}

This study chronicles the recent history and investigates the stock identity of beluga whales (Delphinapterus leucas) in Kotzebue Sound, north-western Alaska, using genetic analysis in concert with a detailed review of field observations and IK. This region was long frequented by belugas, in summer, until their near disappearance in the 1980s (Lucier \& Vanstone 1995; Burns \& Seaman 1986; Seaman et al. 1986; Frost \& Lowry 1990; Huntington et al. 1999). Our genetic study spans the pre- and post-decline periods over four decades (1978-2019).

Belugas once annually returned in large numbers (>1000 individuals) to Kotzebue Sound, an extensive inlet of shallow waters in the south-eastern Chukchi Sea, each summer to feed, calve and rear their young (Burns \& Seaman 1986; Seaman et al. 1986; Lucier \& Vanstone 1995; Figs. 1, 2). The annual seasonal presence of these 


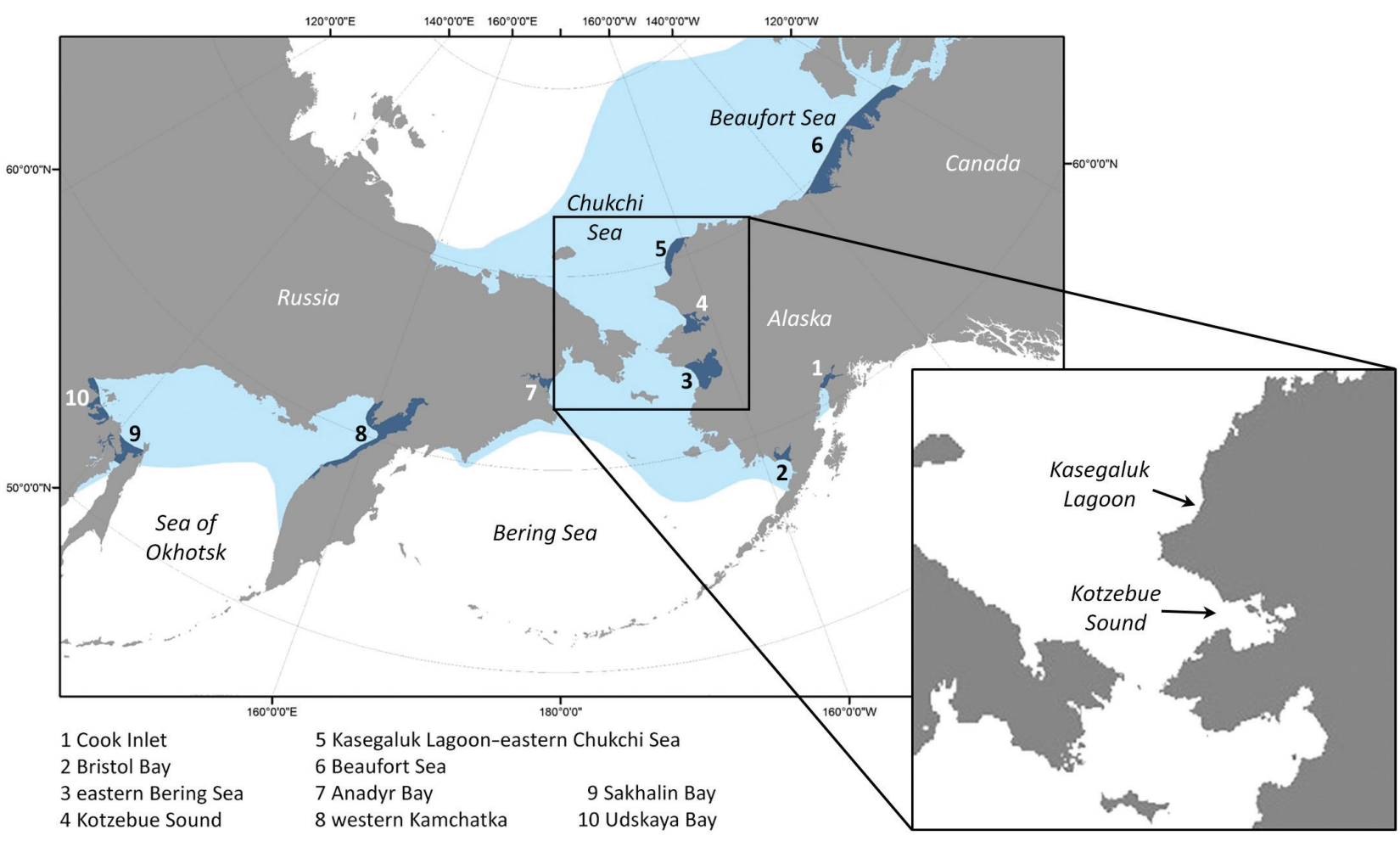

Fig. 1 Distribution (light blue) of beluga whales (Delphinapterus leucas) in the north Pacific Ocean. Ten major summering concentration areas are highlighted in dark blue. The inset details the location of the two primary coastal areas to which beluga whales traditionally returned in summer in the eastern Chukchi Sea: Kotzebue Sound and Kasegaluk Lagoon.

belugas was a central component of the subsistence hunting culture of the Inupiat people of the Kotzebue Sound region that dates back thousands of years (Lucier $\delta$ Vanstone 1995; Burns \& Seaman 1986; Seaman et al. 1986; Frost \& Lowry 1990; Huntington et al. 1999; Seaman et al. 2018). Ethnographic studies in the early 1950s were able to draw directly on Iñupiat knowledge of the annual return of belugas going back to the 1860s and 1870s (Lucier \& Vanstone 1995), and archaeological studies have recorded beluga remains in settlement sites around Kotzebue Sound dating to 2800 before the present (Giddings \& Anderson 1986).

The documentation of IK over the past century and a half, in concert with scientific research in more recent decades, reveals a history of changing hunting methods and shifting whale behaviours, including the disappearance of belugas from culturally important harvest locations, even before the decline of the 1980s. Historically, belugas entered Kotzebue Sound as sea ice broke up in the spring, typically late May or early June (e.g., Burch 1998; Seaman et al. 1986; Seaman et al. 2015; Seaman et al. 2018). Prior to the 1970s, the two most important beluga hunting areas were Sisualik (sometimes spelled Sheshalik; 'place that has beluga whales') and Eschscholtz
Bay (Fig. 2). IK suggested that belugas entered Kotzebue Sound along the northern coast and first passed by Sisualik, where hunters would 'drive' or herd them into shallow waters for harvest (Fig. 2). The hunt at Sisualik was typically complete by mid-July (Burch 1998; Lucier $\&$ Vanstone 1995). Although few harvest records exist prior to the late 1970s, Fejes (1966) noted that $>80$ belugas were harvested at Sisualik in 1958 and Foote 8 Cooke (1966) noted that 52 were harvested there in 1960, suggesting that harvests were once substantial. Belugas typically entered Eschscholtz Bay as the ice retreated in early June; here belugas would enter the shallow bay with incoming tides and exit with outgoing tides (Burch 1998; Huntington et al. 1999; Fig. 2). The harvest at Eschscholtz Bay co-occurred with that at Sisualik and was also typically complete by mid-July (Burch 1998). Again, harvest records prior to the late 1970s are scarce; about 25 belugas were harvested in Eschscholtz Bay in 1951 (Lucier \& Vanstone 1995) and 130 were harvested in 1972 (Alaska Department of Fish \& Game unpubl. data). According to Burch (1998), some belugas were also harvested at the mouth of the Selawik River as late as July or even August, and some belugas were caught in subsistence nets along the southern coast of Kotzebue Sound in July and August. 


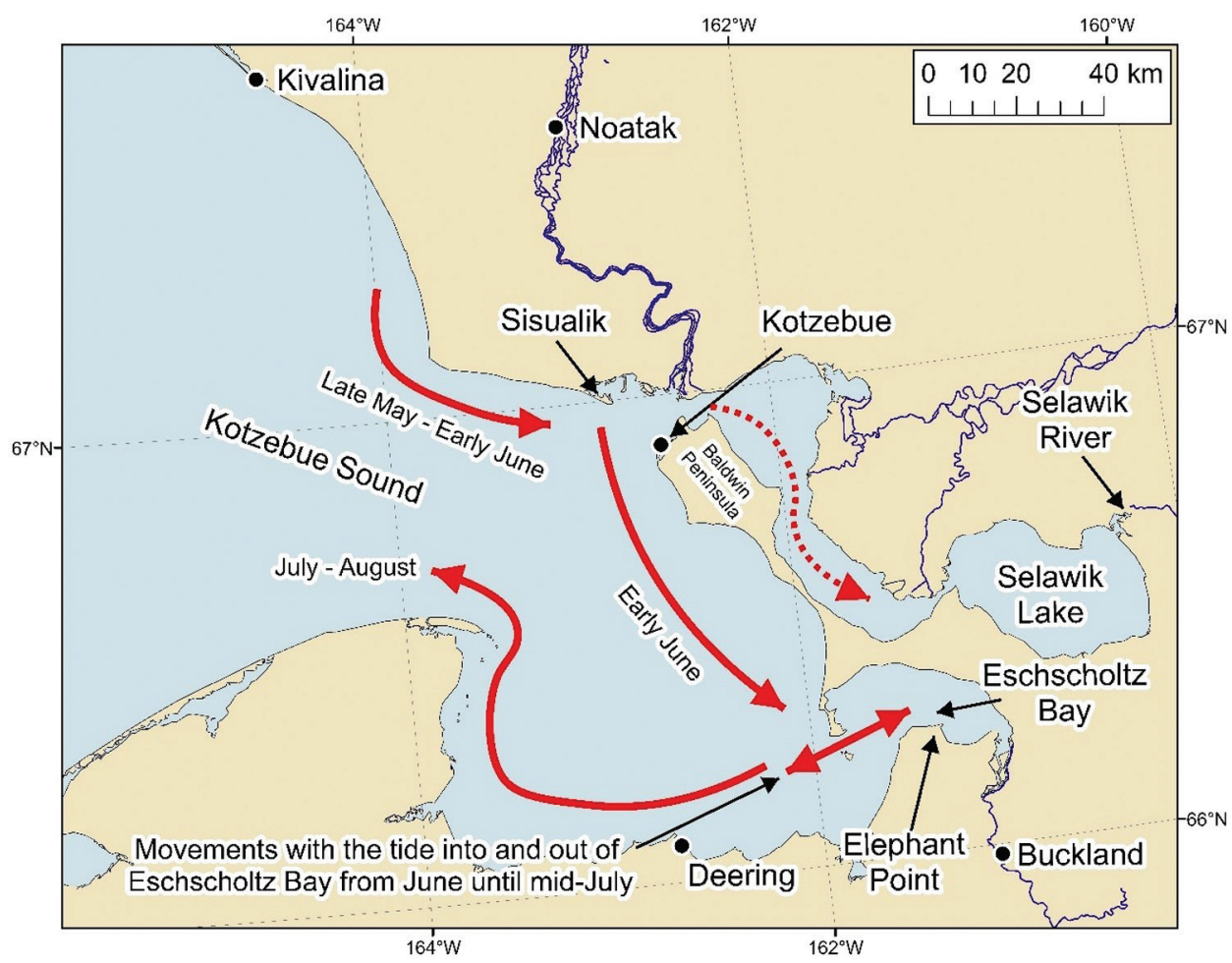

Fig. 2 Map of Kotzebue Sound, including the primary hunting locations of Sisualik and Eschscholtz Bay. Red arrows indicate the movements of belugas on the basis of IK and are adapted from several sources (Burch 1998; Huntington et al. 1999; Lucier \& Vanstone 1995; Morseth 1997; Seaman et al. 2015). Until the 1970s, Sisualik and Eschscholtz Bay were the primary hunting areas, although some belugas were also taken at the mouth of the Selawik River (hence the dotted line) and along the southern sound. After the 1970s, most belugas were harvested in Eschscholtz Bay, although belugas may still be harvested elsewhere at lower numbers.

Although it is unclear how late into summer belugas remained in Kotzebue Sound prior to the 1970s, IK suggests that belugas were less commonly observed after July (Seaman et al. 2018), at least in areas where they were regularly hunted. Frost \& Lowry (1990) compiled sightings and aerial survey data and also concluded that belugas were relatively rare in Kotzebue Sound during late-July and August.

Powerboats were introduced in the 1920s and steadily became faster and more powerful through the 1940s and 1950s (Morseth 1997; Seaman et al. 2015). Beluga hunting became less successful at Sisualik and northern Kotzebue Sound in the late 1950s and early 1960s (Seaman et al. 2015; Seaman et al. 2018). It is unclear if belugas did not return to this area on account of increased disturbance or if the segment of the population that returned to Sisualik and the northern Sound were overharvested. Foote \& Cooke (1960) and Morseth (1997) suggested that belugas were still common in deeper waters, so disturbance may have caused them to avoid shallow inshore areas where they are easier to hunt. Regardless, hunters from Kotzebue and the surrounding communities began to use powerboats to travel to Eschscholtz Bay and Elephant Point to hunt belugas. After the mid-1970s, Elephant Point (Fig. 2) was the primary location for beluga hunting in Kotzebue Sound (Seaman et al. 2018), although belugas were still occasionally taken at Sisualik and other places. Because harvest records were sparse prior to the 1970s, it is unclear whether the total harvest of belugas in Kotzebue Sound declined after hunting at Sisualik became more infrequent or if the increased use of Eschsholtz Bay and Elephant Point compensated for reduced harvest at Sisualik.

A better documented decline in the Kotzebue Sound beluga harvest occurred in the mid-1980s (Fig. 3). Data collected between 1977 and 1984 (Fig. 3) suggests that the beluga harvest was highly variable but large, averaging 84 whales per year during 1977-1983 (maximum of 154 in 1982). The harvest collapsed in 1984 and has yet to recover. Since 1990, harvest has averaged 15 per year $(<10 /$ year in 23 of the last 30 years; ABWC unpubl. data; Fig. 3). The information on abundance that exists also suggests belugas drastically declined in the mid-1980s. In 


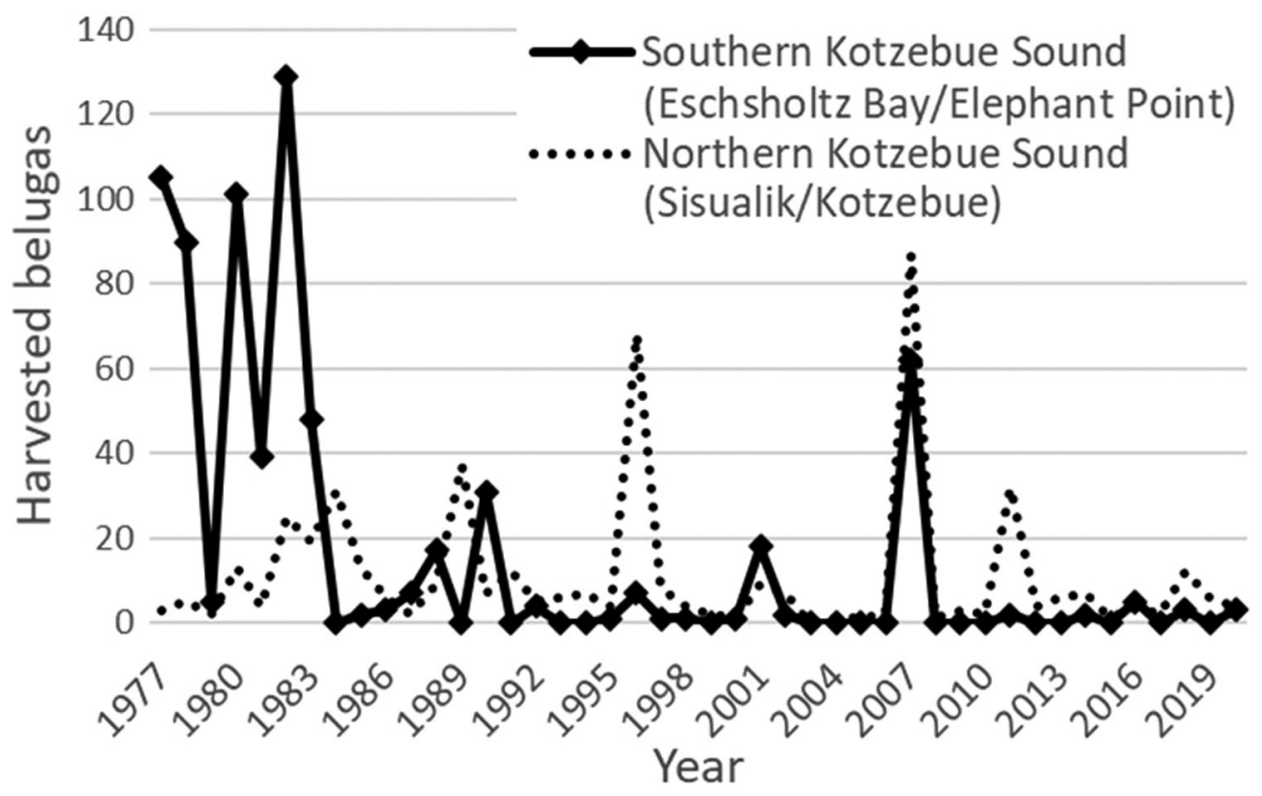

Fig. 3 Subsistence harvest of beluga whales in Kotzebue Sound towards the end of the historical era (1977-1983) and during the contemporary era (1984-2014). The data are for whales landed. Harvest in Southern Kotzebue Sound includes Elephant Point in Eschscholtz Bay; harvest in northern Kotzebue Sound includes Sisualik. Note that beluga harvest in the northern sound (i.e., Sisualik) was low in the 1970s, having declined before harvest data were consistently collected. Atypically large harvests during the contemporary era occurred in 1996 and 2007, when large numbers of whales were again observed in the Sound.

1962, John J. Burns, a co-author, saw 900-1200 belugas in south-eastern Kotzebue Sound. In July 1978, 9001000 were reported in Eschscholtz Bay (Frost \& Lowry 1990). In contrast, in July of 1987, a maximum of 51 belugas was counted on any one day during aerial surveys covering over $4000 \mathrm{~km}$ of trackline (Frost \& Lowry 1990). A year-round passive acoustic monitoring study was conducted between 2014 and 2016 to record cetaceans entering or leaving northern Kotzebue Sound or transiting through the southern Sound. Belugas were detected infrequently (about 20 occasions) in May and from July to January (Castellote et al. 2017). Detections were primarily echolocation click trains of single animals. This contrasted with higher detection rates for killer whales (Orcinus orca), primarily at the mouth of the Sound and for harbour porpoise (Phocoena phocoena), both inside and at the mouth of the Sound (Castellote et al. 2017; Whiting et al. 2019).

The low number of sightings and detections in recent decades has limited other research efforts. Based on satellite tagging studies at other locations, belugas from two other stocks, the eastern Chukchi Sea and the Beaufort Sea, are known to migrate past, but not enter, Kotzebue Sound in spring and autumn (Richard et al. 2001; Luque 8 Ferguson 2010; Hauser et al. 2014; Citta et al. 2016; L. Loseto et al. unpubl. data; Fig. 4). Although satellite-tagged belugas from these two stocks have not entered Kotzebue Sound, it should be noted that the sample size is relatively small.

Why belugas declined in Kotzebue Sound during the 1980s is unknown, but over-harvest, mortality associated with ice-entrapments, increased predation by killer whales, increases in disturbance due to the replacement of kayaks and umiaks by motorized boats, or a combination of these, may have played roles (Burns \& Seaman 1986; Seaman et al. 1986; Frost \& Lowry 1990; Huntington et al. 1999; Seaman et al. 2015).

It is unclear whether the Kotzebue Sound belugas altered their traditional migratory behaviour some time in the 1980s (perhaps to avoid the region) and, if so, whether this involved displacement to new areas or the contraction of their range such that they continued to return to other traditional coastal areas in the Chukchi Sea each summer. Alternatively, the Kotzebue Sound belugas may be a genetically distinct subpopulation or stock that suffered significant depletions from which they have yet to recover. To address these questions, assess the current status of Kotzebue Sound belugas and develop meaningful management strategies, the genetic identity and differentiation of Kotzebue Sound belugas, past and present, must be resolved. The decline in beluga numbers has resulted in a near collapse of the traditional 


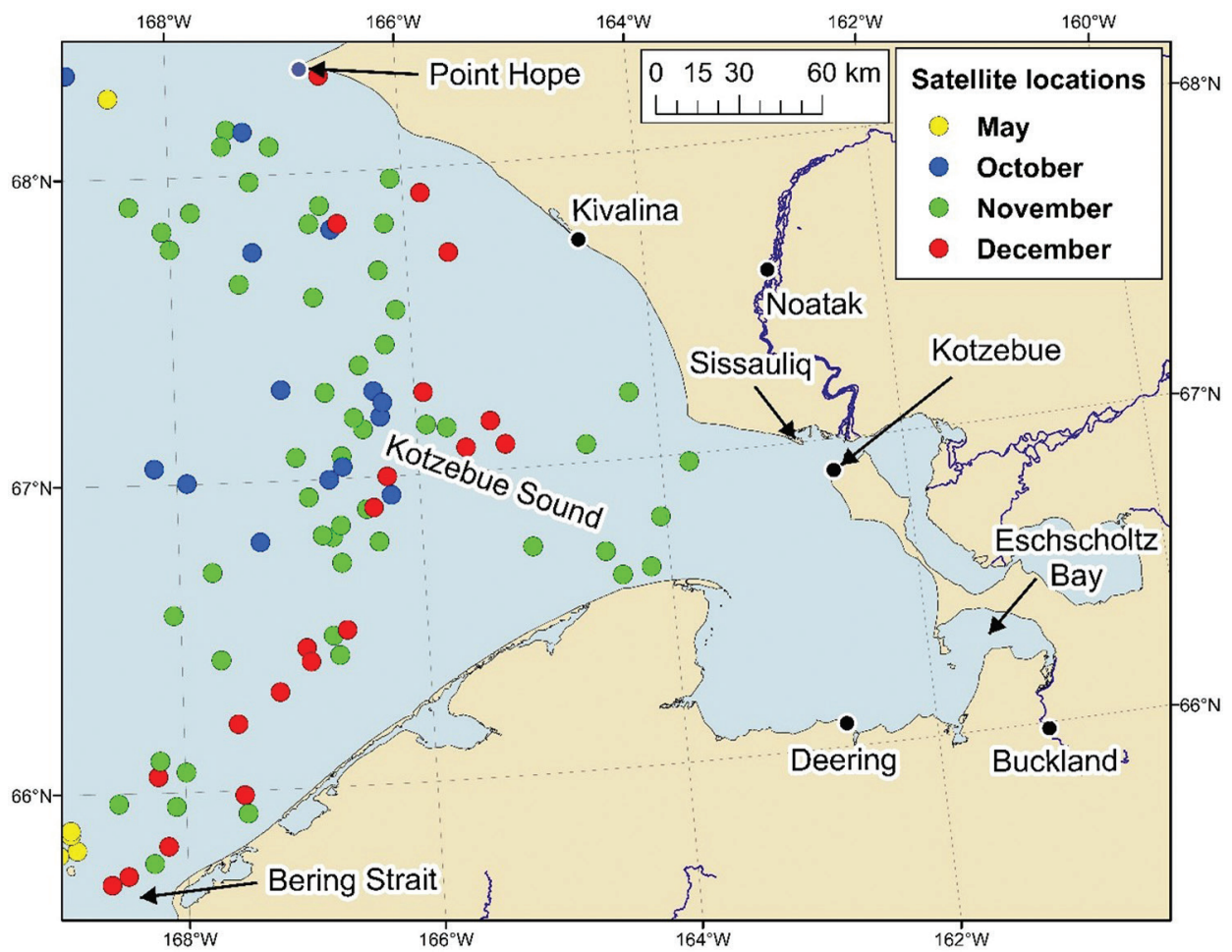

Fig. 4 Average daily locations from beluga satellite tagged whales in the eastern Chukchi Sea stock, presented by month of occurrence. Data were processed according to Citta et al. (2018). Eastern Beaufort Sea stock belugas also have satellite locations in this region in spring and fall; however, there are no satellite locations within inner Kotzebue Sound (L. Loseto, pers comm.).

subsistence beluga hunt in Alaska Native communities around Kotzebue Sound, almost ending an age-old relationship between the Iñupiat and the belugas of the region (Frost \& Lowry 1990; Huntington et al. 1999; Seaman et al. 2015; Seaman et al. 2018). Lending additional urgency to the need to determine whether the beluga whales of Kotzebue Sound were a distinct stock, and if that stock still exists, is the MMPA's requirement that actions be taken to replenish a stock that is designated as depleted. The MMPA considers a marine mammal stock depleted if it is below the optimum sustainable population level, which is generally considered to be $50 \%-70 \%$ of the largest population the habitat can support.

Genetic studies have been conducted on population structure, dispersal patterns and stock identity of belugas in Alaskan waters. Some included samples from Kotzebue Sound collected before the mid-1980s decline, termed here the historical era, and after the decline, to which we refer as the contemporary era. The earliest genetic research involving Kotzebue Sound whales used mtDNA and revealed that belugas harvested in the Sound during the contemporary era (1994-96) were substantially different from other stocks, including from belugas that were harvested farther north each summer near Kasegaluk Lagoon (O'Corry-Crowe et al. 2002; Fig. 1). Those findings were the first evidence that Kotzebue Sound belugas were likely not part of the eastern Chukchi Sea stock, which was originally thought to include belugas that occurred in summer in Kotzebue Sound and near Kasegaluk Lagoon (Burns \& Seaman 1986; Frost \& Lowry 1990). The limited sample size $(n=20)$, predominance of a single year in the sample set that may have included an unusual migration event (1996, see below) and reliance on a single marker (mtDNA) limited further inference at that time. Subsequent mtDNA analyses found that belugas sampled during the historical era (1978-1982) were significantly different from all other known stocks in the North Pacific Ocean except Bristol Bay (O'Corry-Crowe et al. 2016; O'Corry-Crowe et al. 2018). They were also found to differ from whales sampled in Kotzebue Sound during the contemporary period. Here too, however, limited sample size $(n=39)$, and the predominance of samples from a single year (1982) during the historical period, prevented further analysis of stock origins.

To further complicate matters, there is evidence that belugas of other stocks may sometimes enter Kotzebue Sound. The contemporary era in Kotzebue Sound has 
been dominated by two events, one in 1996 and another in 2007, when unusually large numbers of belugas entered Kotzebue Sound and relatively large numbers were harvested (Fig. 3). The most recent genetic studies increased the sample size $(n=80)$ and time frame (19942007) for the contemporary era, added nuclear markers (nDNA) and found that the genetic profiles (mtDNA + nDNA) of samples collected in 1996 and 2007 showed strong similarities to the Beaufort Sea stock (O'CorryCrowe et al. 2016; O'Corry-Crowe et al. 2018). These events coincided with low ice years, and in 2007, with an increase in killer whale sightings and observed predation on belugas in Kotzebue Sound. Assignment tests indicated that these events most likely involved belugas from the Beaufort Sea stock that entered Kotzebue Sound during those summers (O'Corry-Crowe et al. 2016; $\mathrm{O}^{\prime}$ Corry-Crowe et al. 2018).

Key questions regarding the stock composition of belugas within Kotzebue Sound remain unanswered. In this study, we address three questions: (1) were belugas that frequented Kotzebue Sound prior to the decline in the mid-1980s a demographically distinct subpopulation that is now greatly depleted?; (2) are the belugas that enter Kotzebue Sound in summer during the contemporary era from a single stock or a mix of stocks?; and (3) what stock or stocks are contemporary belugas from? Here, we use a larger sample size $(n=165)$ and an expanded sampling period (1978-2019) than available in prior studies (O'Corry-Crowe et al. 2002; O'Corry-Crowe et al. 2016; O'Corry-Crowe et al. 2018), including multiple well-sampled years from the historical era that enable assessments of genetic and demographic stability in the years before the decline and new samples from the period 2008-2019 that facilitate assessments of stability in the genetic signal and stock origins in the most recent decade. We also conduct new analyses, including exclusion tests in concert with assignment tests, to assess whether Kotzebue Sound belugas harvested during the contemporary era came from more than one stock. We also investigate the possibility that belugas with very low likelihoods of occurring in any of the known stocks in the BeringChukchi-Beaufort region indicate the existence of a remnant Kotzebue Sound stock.

\section{Methods}

Total DNA was extracted from contemporary tissue samples and screened for variation within 410 bps of the mtDNA and for polymorphism within eight hypervariable microsatellite markers (nDNA), according to previously published methods (O'Corry-Crowe et al. 1997; O'Corry-Crowe et al. 2010; O'Corry-Crowe et al. 2018). Evidence of allelic dropout or null alleles in the nDNA markers was assessed using MICRO-CHECKER (version 2.2.3; van Oosterhout et al. 2004). Total DNA was extracted from teeth representing the historical era using methods for the recovery of aDNA (Höss \& Pääbo 1993; Rohland $\&$ Hofreiter 2007) and screened for sequence variation in the 410 bp mtDNA fragment. To ensure efficacy in our aDNA recovery methods extractions were typically done on a maximum of three samples at any one time, and negative extraction controls as well as polymerase chain reaction controls were used. The characterization of the mtDNA target region required successful sequencing of both the forward and reverse strand of three shorter overlapping fragments. No nDNA analysis was performed on the teeth samples because of the low DNA quantity. As a consequence, we were not able to include the historical Kotzebue Sound samples in the nDNA analyses. Previously published mtDNA and nDNA data from 1474 belugas from nine populations and recognized stocks were used in some of the analyses. The sampled belugas were from Cook Inlet, Bristol Bay, eastern Bering Sea, eastern Chukchi Sea, Beaufort Sea, Anadyr Bay and three populations in the Okhotsk Sea (Table 1; Meschersky et al. 2013; O'Corry-Crowe et al. 2018).

Population structure and the population-of-origin of individual belugas from Kotzebue Sound were assessed using: (i) homogeneity tests of genetic differentiation in ARLEQUIN (version 3.5; Excoffier \& Lischer 2015), (ii) assignment tests using WHICHRUN (version 4.1; Banks \& Eichert 2000), (iii) exclusion tests using Geneclass (version 2.0; Piry et al. 2004) and (iv) searches of GenBank ${ }^{\circledR}$ (National Center for Biotechnology Information, National Institutes of Health). The first two approaches were performed according to our previously published methods (O'Corry-Crowe et al. 2015; O'Corry-Crowe et al. 2018). In the assignment tests, we used previously identified stocks (O'Corry-Crowe et al. 2015; O'CorryCrowe et al. 2018) as reference (i.e., source) stocks, including the three stocks in the Bering Sea (Anadyr Gulf, Bristol Bay and eastern Bering), as well as the eastern Chukchi Sea and the Beaufort Sea stocks (Fig. 1, Tables 2, 3). Each Kotzebue Sound beluga was assigned to the reference stock where that beluga's genetic profile (nDNA or nDNA-mtDNA combined) was estimated to most likely arise, based on observed allelic frequencies and Hardy-Weinberg assumptions (nDNA) and on observed haplotype (mtDNA) frequencies (Banks \& Eichert 2000). Confidence in assignments was based on the ratio of the likelihood functions of the most likely stock to that of the second most likely. We chose a ratio of $10, \log _{10}$-transformed to a $\log$ ratio (logarithm of the odds) score of 1.0 , to 


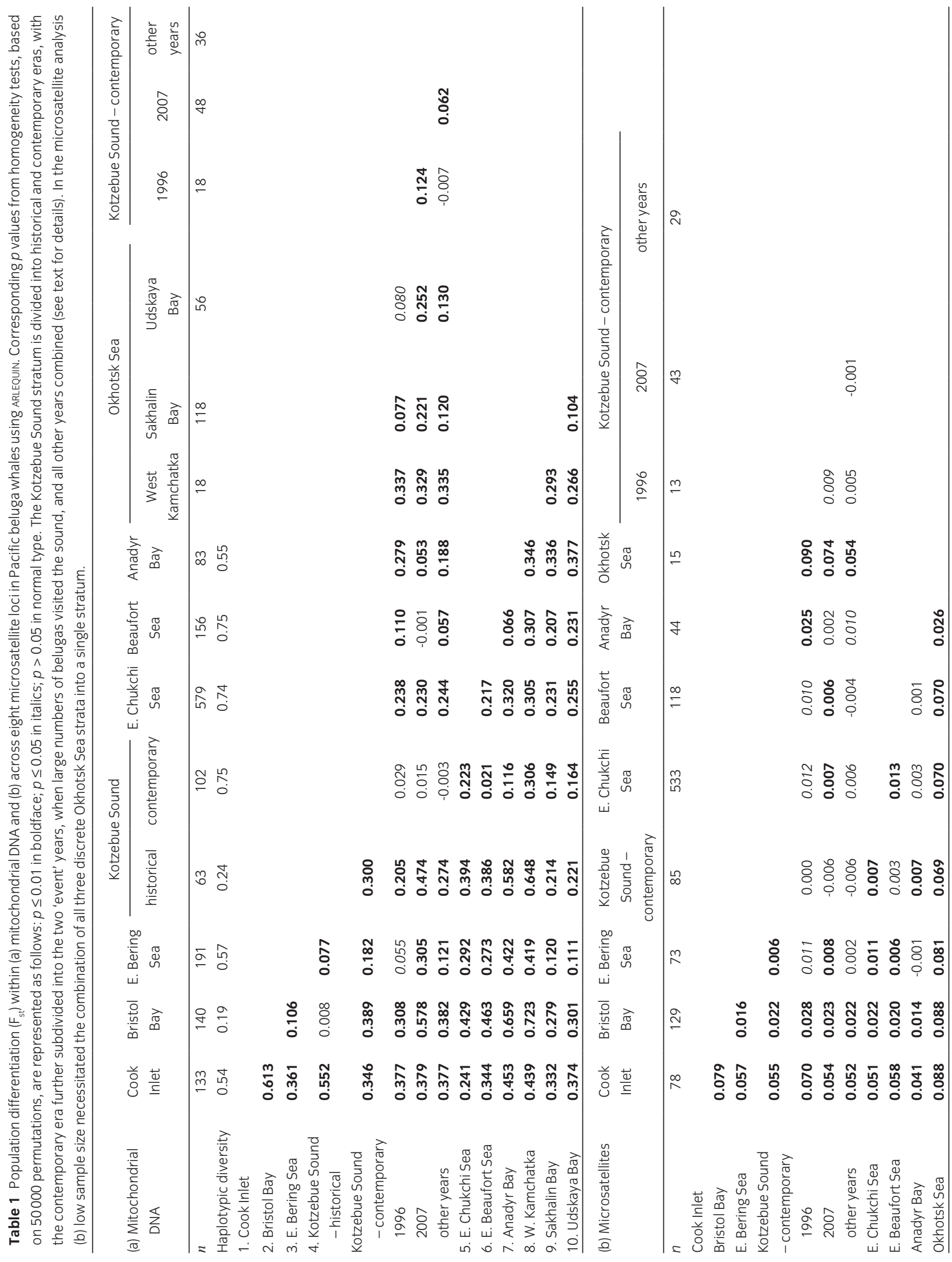


Table 2. Summary of assignment test outcomes using WHICHRUN on 85 beluga whales sampled in Kotzebue Sound during the contemporary era. Each individual was assigned to one of five known (reference) stocks in the Bering, Chukchi and Beaufort seas on the basis of which stock had the highest estimated probability of that individual's genetic profile (based on nDNA markers or on nDNA and mtDNA combined) arising in that stock. Confidence in the assignment was estimated using log-ratio (LOD) scores with an LOD $\geq 1$ indicating high confidence that the assigned stock was the most probable of the reference stocks surveyed.

\begin{tabular}{|c|c|c|c|c|}
\hline \multirow{2}{*}{$\begin{array}{l}\text { Reference } \\
\text { stock }\end{array}$} & \multicolumn{2}{|c|}{ nDNA } & \multicolumn{2}{|c|}{ nDNA-mtDNA } \\
\hline & $\begin{array}{c}\text { Highest } \\
\text { probability }\end{array}$ & $L O D \geq 1.0$ & $\begin{array}{c}\text { Highest } \\
\text { probability }\end{array}$ & $\mathrm{LOD} \geq 1.0$ \\
\hline Bristol Bay & 11 & 0 & 11 & 1 \\
\hline E Bering Sea & 15 & 2 & 19 & 4 \\
\hline E Chukchi Sea & 16 & 1 & 4 & 1 \\
\hline Beaufort Sea & 29 & 1 & 36 & 15 \\
\hline Anadyr Bay & 14 & 3 & 15 & 4 \\
\hline Totals & 85 & 7 & 85 & 25 \\
\hline
\end{tabular}

denote high confidence in the assigned stock. In the exclusion analysis we computed the probability that an individual could belong to a reference stock by comparing its genotype's likelihood of occurring in each reference stock to the genotype likelihoods of a number ( $n=1000$ and $n=10000)$ of simulated individuals (based on Monte-Carlo resampling) from each stock according to the method of Paetkau et al. (2004). The Type-1 error level of the resultant distribution acted as the exclusion criterion (Piry et al. 2004). Kotzebue Sound belugas that had low genotype likelihoods relative to the simulated individuals (e.g., $<\alpha=$ 0.05 ) for a particular stock were considered not to come from that stock.

Finally, the incidence of mtDNA haplotypes and nDNA alleles that have only been recorded in Kotzebue Sound were compared to the frequency of unique and rare haplotypes and alleles characteristic of other known stocks, in order to assess whether sampling artefacts (e.g., low sample sizes) versus real stock differences may explain the presence of haplotypes or alleles found only in Kotzebue Sound that have not been found elsewhere. This included searching the GenBank® sequence database using the BLAST tool, which facilitated range-wide comparisons across all known mtDNA studies of beluga whales with sequences homologous to the current study.

\section{Results}

DNA was extracted from skin samples or teeth of 182 belugas harvested in Kotzebue Sound over a 41-year period (1978-2019). A total of 165 whales yielded DNA of sufficient quality and quantity for genetic profiling, 119 from earlier studies (O'Corry-Crowe et al. 2002; O'CorryCrowe et al. 2016; O'Corry-Crowe et al. 2018) and 46 not previously analysed. Of the 46 individuals, 24 were successfully sequenced for the entire 410 bp haplotype, which substantially increased the sample size for the historical era (1978-1982) from 39 to 63 (Table la). In addition, combined mtDNA-nDNA profiles were generated for 22 new samples collected from 2008 to 2019. This increased the sample size for the contemporary era (19942019) from 80 to 102 for mtDNA (Table la) and from 63 to 85 for nDNA (Table $1 \mathrm{~b}$ ). This also greatly increased the temporal span (adding the years 2008-2019) and statistical power of the data set from the contemporary era.

\section{mtDNA analyses}

Analysis of patterns of mtDNA variation showed that Kotzebue Sound belugas sampled during the historical era were statistically different from all but one other stock of beluga whales in the Pacific Arctic, including those geographically most proximate $\left(F_{\mathrm{st}}=0.077-0.552, p<\right.$ 0.003; Table 1, Fig. 5). The one exception was Bristol Bay $\left(F_{\text {st }}=0.01, p=0.142\right.$; Table 1$)$, a resident stock in the south-eastern Bering Sea (Fig. 1). The lack of significant differentiation is attributed to the very high frequency of one widespread haplotype (light orange colour in Fig. 5) in both. However, none of the other nine haplotypes documented in Kotzebue Sound during the historical era and in Bristol Bay were shared (Fig. 5). To maximize temporal comparability with historical samples from Kotzebue Sound, we analysed samples collected from other stocks during a similar period (late-1970s to mid-1980s). Here too, the Kotzebue Sound belugas were statistically different from whales sampled from the eastern Chukchi Sea and Beaufort Sea stocks $\left(F_{\mathrm{st}}=0.427-0.483, p<0.001\right)$. The expanded aDNA data set allowed us to compare across years during the historical era within Kotzebue Sound. The pattern of mtDNA diversity in the late 1970s and early 1980s was quite consistent $\left(F_{\mathrm{st}}=0.001, p=\right.$ 0.443 ), indicating that belugas in those years were likely from the same stock.

The analysis of Kotzebue Sound belugas sampled during the contemporary era yielded a very different picture (Table 1, Fig. 5). Statistically significant differences in mtDNA were found between contemporary and historical samples $\left(F_{\mathrm{st}}=\right.$ $0.3, p<0.001)$. Collectively, mtDNA from contemporary samples was substantially different from almost all other stocks in the marginal seas of the Pacific Arctic (Table 1, Fig. $5)$, the one exception being a low but significant degree of heterogeneity $\left(F_{\mathrm{st}}=0.021, p=0.007\right)$ when compared with the Beaufort Sea stock. In contrast to the historical era, the 
Table 3. Summary of findings from assignment tests using WHICHRUN and exclusion tests using GENECLASS. A subset of individuals is presented for each of the six possible outcomes in terms of the number of reference stocks excluded (i.e., $n=0$ to $n=5$ ), based on a statistical threshold using Monte Carlo resampling methods. The following is provided for each individual: (1) its mtDNA haplotype, indicating those haplotypes that have been found only in Kotzebue to date; (2) the stock it was assigned to on the basis of nDNA (microsatellites) and on combined nDNA-mtDNA likelihood functions along with the confidence (i.e., log-ratio [LOD]) scores in those assignments; and (3) its genotype's likelihood of arising in each stock relative to $n=10000$ simulated individuals from that same stock with boldface and italics representing likelihoods that exclude the test individual from the reference stock at the $\alpha=0.05$ (italics) or $\alpha=0.01$ (boldface) level.

\begin{tabular}{|c|c|c|c|c|c|c|c|c|c|c|c|}
\hline \multirow[b]{2}{*}{$\begin{array}{l}\text { Kotzebue } \\
\text { individual ID }\end{array}$} & \multirow[b]{2}{*}{$\begin{array}{c}\text { mtDNA } \\
\text { haplotype }\end{array}$} & \multicolumn{3}{|r|}{ WHICHRUN } & \multicolumn{7}{|c|}{ GENECLASS } \\
\hline & & nDNA & LOD & nDNA-mtDNA & LOD & $\begin{array}{c}\text { Bristol } \\
\text { Bay }\end{array}$ & $\begin{array}{l}\text { E. Bering } \\
\text { Sea }\end{array}$ & $\begin{array}{c}\text { E. Chukchi } \\
\text { Sea }\end{array}$ & $\begin{array}{l}\text { Beaufort } \\
\text { Sea }\end{array}$ & $\begin{array}{c}\text { Anadyr } \\
\text { Bay }\end{array}$ & $\begin{array}{l}\text { No. of } \\
\text { reference } \\
\text { stocks } \\
\text { excluded }\end{array}$ \\
\hline KzH161 & 5 & Beaufort Sea & 0.24 & E. Bering Sea & 0.13 & 0.159 & 0.556 & 0.663 & 0.817 & 0.062 & 0 \\
\hline KzH162 & 9 & Beaufort Sea & 0.40 & Beaufort Sea & 0.94 & 0.123 & 0.371 & 0.212 & 0.513 & 0.103 & 0 \\
\hline KzH168 & 9 & Beaufort Sea & 0.23 & Beaufort Sea & 0.52 & 0.086 & 0.385 & 0.281 & 0.480 & 0.117 & 0 \\
\hline KzH170 & $55^{b}$ & Beaufort Sea & 0.44 & Beaufort Sea & 0.62 & 0.429 & 0.539 & 0.654 & 0.802 & 0.199 & 0 \\
\hline KzH119 & 5 & E. Bering Sea & 0.47 & E. Bering Sea & 1.55 & 0.044 & 0.588 & 0.434 & 0.321 & 0.204 & 1 \\
\hline KzH120 & $65^{b}$ & E. Chukchi Sea & 0.05 & E. Bering Sea & 0.22 & 0.098 & 0.471 & 0.477 & 0.519 & 0.031 & 1 \\
\hline KzH138 & 9 & Beaufort Sea & 0.26 & Beaufort Sea & 1.29 & 0.111 & 0.069 & 0.106 & 0.371 & 0.030 & 1 \\
\hline $\mathrm{KzH} 146$ & $67^{b}$ & Bristol Bay & 0.26 & Bristol Bay & 0.01 & 0.071 & 0.112 & 0.061 & 0.067 & 0.027 & 1 \\
\hline KzH134 & $55^{b}$ & E. Chukchi Sea & 0.37 & E. Bering Sea & 0.20 & 0.007 & 0.098 & 0.123 & 0.083 & 0.021 & 2 \\
\hline $\mathrm{KzH} 140$ & 9 & Beaufort Sea & 0.54 & Beaufort Sea & 1.74 & 0.018 & 0.155 & 0.312 & 0.592 & 0.040 & 2 \\
\hline KzH148 & 9 & Beaufort Sea & 0.67 & Beaufort Sea & 2.23 & 0.008 & 0.250 & 0.139 & 0.470 & 0.004 & 2 \\
\hline KzH195 & 2 & Beaufort Sea & 0.63 & Beaufort Sea & 0.13 & 0.001 & 0.100 & 0.058 & 0.208 & 0.001 & 2 \\
\hline KzH130 & 21 & E. Chukchi Sea & 2.25 & E. Chukchi Sea & 1.35 & 0.021 & 0.046 & 0.516 & 0.091 & 0.008 & 3 \\
\hline KzH132 & 14 & E. Chukchi Sea & 0.29 & Beaufort Sea & 0.45 & 0.024 & 0.040 & 0.211 & 0.180 & 0.027 & 3 \\
\hline KzH154 & 14 & Beaufort Sea & 0.50 & Beaufort Sea & 1.24 & 0.037 & 0.039 & 0.090 & 0.191 & 0.000 & 3 \\
\hline Kz4543 & $27^{b}$ & Beaufort Sea & 0.76 & Beaufort Sea & 0.5 & 0.005 & 0.197 & 0.027 & 0.413 & 0.037 & 3 \\
\hline Kz6350 a & 6 & E. Chukchi Sea & 0.30 & Beaufort Sea & 0.30 & 0.002 & 0.003 & 0.075 & 0.058 & 0.007 & 3 \\
\hline Kz8425 & 9 & Beaufort Sea & 1.28 & Beaufort Sea & 2.35 & 0.001 & 0.018 & 0.029 & 0.162 & 0.003 & 4 \\
\hline KzH158 & 9 & Beaufort Sea & 0.88 & Beaufort Sea & 2.44 & 0.014 & 0.045 & 0.016 & 0.128 & 0.002 & 4 \\
\hline KzH6724 & 9 & Beaufort Sea & 0.32 & Beaufort Sea & 0.17 & 0.003 & 0.019 & 0.004 & 0.151 & 0.041 & 4 \\
\hline $\mathrm{KzH} 172^{a}$ & 9 & Beaufort Sea & 0.29 & Beaufort Sea & 0.52 & 0.002 & 0.037 & 0.019 & 0.073 & 0.009 & 4 \\
\hline $\mathrm{KzH} 133^{a}$ & 9 & Anadyr Bay & 1.36 & Anadyr Bay & 1.52 & 0.010 & 0.023 & 0.018 & 0.031 & 0.079 & 4 \\
\hline KzH153 & 9 & Beaufort Sea & 0.04 & Beaufort Sea & 1.37 & 0.000 & 0.032 & 0.005 & 0.029 & 0.001 & 5 \\
\hline KzH181 & 9 & E. Chukchi Sea & 0.23 & Beaufort Sea & 0.34 & 0.001 & 0.011 & 0.012 & 0.004 & 0.001 & 5 \\
\hline Kz12213 & 9 & E. Bering Sea & 1.33 & Anadyr-E. Bering & 0.00 & 0.000 & 0.011 & 0.007 & 0.002 & 0.000 & 5 \\
\hline
\end{tabular}

a Individuals excluded from all reference stock at the $\alpha \leq 0.1$ level. ${ }^{b}$ Haplotypes that have only been found in Kotzebue Sound to date.

contemporary belugas of Kotzebue Sound were characterized by a high level of mtDNA haplotypic diversity $(\mathrm{H}=0.75$ versus $\mathrm{H}=0.24$; Table 1 , Fig. 5). The contemporary sample set spanned 25 years and included two anomalous events when relatively large numbers of whales occurred in Kotzebue Sound: 1996 and 2007. Analysis revealed that the limited differentiation recorded between the contemporary era and the Beaufort stock was primarily driven by the 2007 event $\left(F_{\text {st }}=-0.001, p=0.436\right.$; Table 1, Fig. 5). By contrast, the substantial differentiation between the historical and contemporary data sets was also driven primarily by this same event $\left(F_{\mathrm{st}}=0.474, p<0.0001\right)$.

All known stocks that we investigated, except for Cook Inlet, were found to possess one or more unique
mtDNA haplotypes, that is, haplotypes not found elsewhere (Fig. 5). Kotzebue Sound belugas had a relatively high number of unique haplotypes $(n=7)$, most of which were recorded during the contemporary era. Furthermore, none of these haplotypes were found in GenBank ${ }^{\circledR}$ searches, which included several mtDNA studies of beluga whales across the species' range. One of the unique haplotypes from Kotzebue Sound (coloured red and located near the top of the Kotzebue bar charts in Fig. 5) was recorded in both eras (1981 and again in 2007). The additional samples from the most recent period (i.e., 2008-2019) had a high diversity of mtDNA lineages $(H=0.74)$, especially when compared to the historical era $(\mathrm{H}=0.24)$. As well as including a 


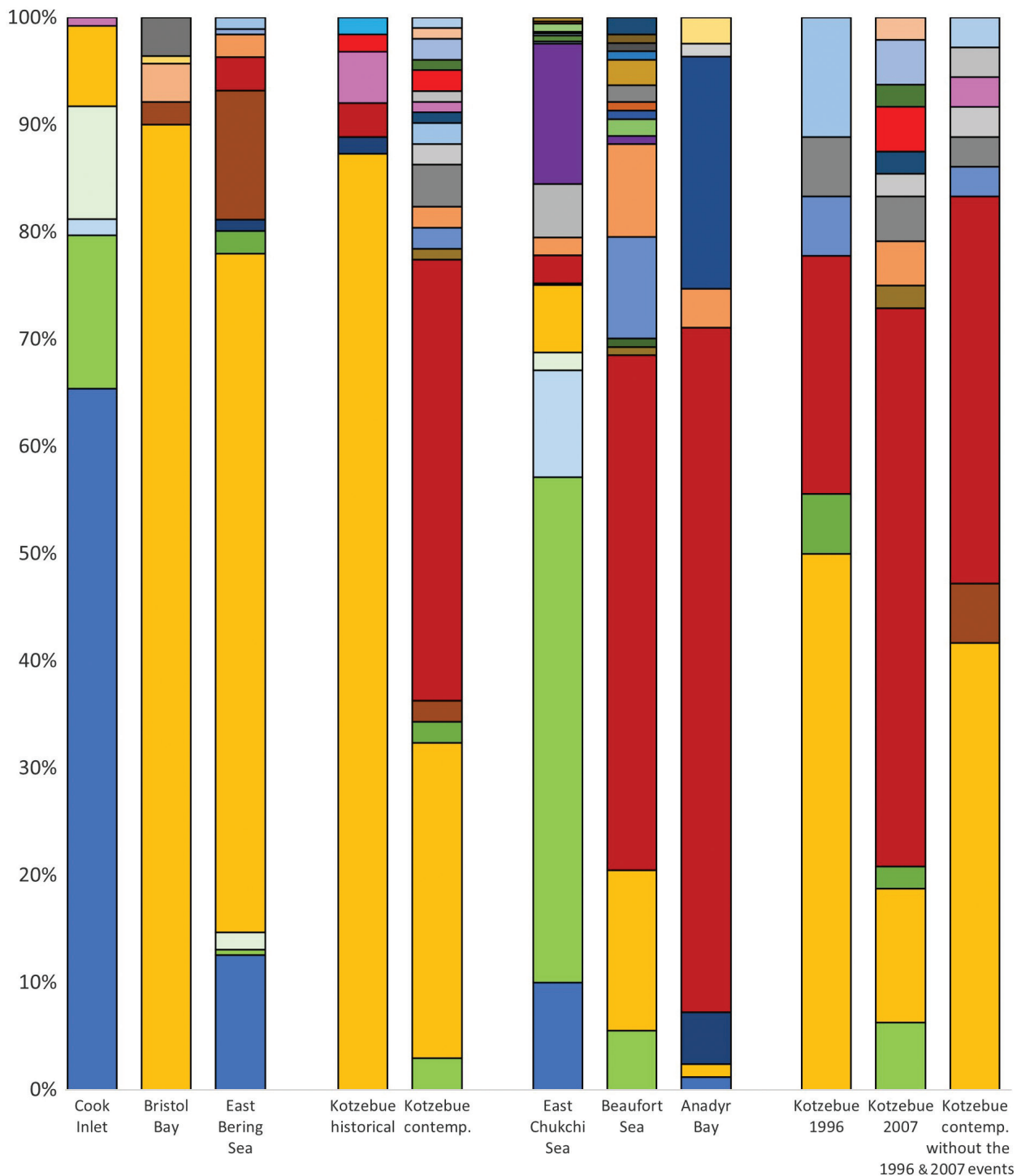

Fig. 5 Diversity in mtDNA (i.e., haplotype) in beluga whales in Cook Inlet, the Bering Sea (Bristol Bay, eastern Bering Sea and Anadyr Bay), the Chukchi Sea (Kotzebue Sound, eastern Chukchi Sea) and the Beaufort Sea. Each unique mtDNA lineage (haplotype) is represented by a different colour. The final three columns represent three elements of the contemporary era, including two anomalous events, one in 1996 and the other in 2007 . The unique haplotypes representing the historical Kotzebue Sound stock are the red and blue at the top of that column.

number of lineages common to the earlier Kotzebue samples and to the Beaufort Sea, these new samples contained a number of lineages that we had not observed in Kotzebue Sound to date and include a new haplotype, a haplotype recorded only once before in the Yukon delta in the Bering Sea and a haplotype characteristic of the eastern Bering Sea stock.

\section{nDNA analyses}

Contemporary samples were also screened for nDNA variation. As stated above, we were unable to screen
nDNA from tooth samples and were therefore unable to examine nDNA variation in the historical Kotzebue Sound samples. Nuclear markers from the contemporary samples were found to differ significantly from those in other stocks, including Cook Inlet, the Okhotsk Sea and all stocks in the Bering-Chukchi-Beaufort region (Table 1). However, the level of differentiation in some cases was quite low $\left(F_{\mathrm{st}}=0.003-0.007\right)$ and further analysis of the contemporary samples failed to detect differences among some stocks and we found no nDNA alleles in the Kotzebue Sound samples that were not found in at least one other stock across the Pacific Arctic. 
The WHICHRUN and GENECLASS analyses revealed that the genetic profiles of the contemporary Kotzebue Sound belugas tended to have very low likelihoods of arising in either the Gulf of Alaska (i.e., Cook Inlet) or the Sea of Okhotsk regions. The majority were excluded from both regions with a high degree of confidence $(p<0.001)$. This is not surprising considering the geographic distance from Kotzebue Sound to the Gulf of Alaska and to the Sea of Okhotsk (Fig. 1). Contemporary Kotzebue Sound belugas $(n=85)$ were assigned to the Beaufort Sea stock more frequently than to the other reference stocks in the Pacific Arctic (i.e., Bristol Bay, eastern Bering Sea, eastern Chukchi Sea and Anadyr Bay) based on both genotypic likelihoods and on combined genotypic-haplotypic likelihoods (Tables 2, 3). However, three of the 85 belugas sampled in Kotzebue Sound during the contemporary era were excluded from all of the reference stocks, including the Beaufort Sea stock (Table 3). This indicates that some belugas, although assigned to one of the five known (i.e., reference) stocks in the Bering-Chukchi-Beaufort region, based on genotypic likelihoods using assignment tests (WHichrun), were excluded from that stock using the exclusion test (GENECLASS).

\section{Discussion}

Based on IK, field studies and the findings we present here, it is evident that belugas in Kotzebue Sound once comprised a separate stock. Belugas that summered in Kotzebue Sound prior to the mid-1980s decline were significantly different from all other known populations in the Pacific Arctic and Subarctic with respect to maternally inherited mtDNA. Although this has been alluded to before (e.g., O'Corry-Crowe et al. 2002; O'Corry-Crowe et al. 2018; Lowry et al. 2019), clear evidence was not available until now. Significantly, the added historical-era samples in the current study established that the genetic signature before the decline was stable across years. This provides crucial evidence of a likely stable pattern of return to Kotzebue Sound by the same population of beluga whales year after year (see below). By contrast, the newest samples from the contemporary era provide further evidence of a highly variable genetic picture since the decline. Earlier studies of this period were dominated by two events, one in 1996 the other in 2007, which revealed that whales from another stock (or stocks), specifically the Beaufort Sea, likely entered the Sound in those summers ( $\mathrm{O}^{\prime} \mathrm{C}$ corryCrowe et al. 2002; O'Corry-Crowe et al. 2018 Lowry et al. 2019). The samples collected since then now reveal that even outside of these two notable events, the genetic signature in Kotzebue Sound has not stabilized and includes mtDNA lineages recorded in Kotzebue Sound during the historical era, some of which are unique to the Sound.
They also include new lineages not recoded before, and lineages typically found at locations south as well as north of the Bering Strait. This suggests that the current pattern of use of Kotzebue Sound may be quite dynamic, with a likely remnant population that, at times, co-occurs with whales from other stocks.

A recent genetic study of population structure and stock identity of belugas in the North Pacific concluded that substantial mtDNA differentiation among summering concentrations likely indicated limited dispersal and long-established female-mediated philopatry to separate summering areas (O'Corry-Crowe et al. 2018). Thus, those summering aggregations were likely demographically discrete subpopulations (Avise 1995; O'Corry-Crowe et al. 2018). At decadal scales, temporal comparisons within summering concentrations showed no changes in mtDNA or nDNA, and kinship analysis using the nDNA data confirmed philopatry to a summering area across multiple generations. Such fidelity to natal summering locations provided strong evidence that individual whales likely inherit knowledge of traditional migratory pathways and destinations from other community members, possibly via social learning. This relationship between mtDNA differentiation and demographic independence in beluga whale populations, when combined with the consistent pattern of genetic diversity and differentiation across years recorded in our current study, likely indicate that the belugas that returned to Kotzebue Sound prior to the mid-1980s were a demographically distinct subpopulation. Demographic independence is the fundamental criterion for the identification of distinct population stocks under the MMPA (Wade \& Angliss 1997; NMFS 2005). Our findings indicate belugas that annually frequented Kotzebue Sound in summer, during the historical era, meet the legal definition of a distinct stock.

What is less clear is whether the historical Kotzebue Sound stock still exists. Contemporary genetic comparisons were hampered by limited sample size and inability to extract sufficient DNA for nDNA analysis from teeth obtained during the pre-decline period. This created challenges for determining whether belugas that occurred in Kotzebue Sound each summer during the contemporary era were from a single stock or a mix of stocks. The mtDNA results indicate that belugas now harvested in Kotzebue Sound have significantly different genetic profiles than those of the historical era and the genetic profile of contemporary whales has similarities to belugas from the Beaufort Sea stock (Fig. 5). These findings were heavily influenced by 66 of 102 individuals sampled in two years, 1996 and 2007, when large numbers of belugas were in the Sound in June and July. In 2007, whales were primarily adult males (46 of 48 sequenced) and were beyond what is thought to be the normal range for 
Beaufort Sea belugas during July. Adult males are known to roam farther than mixed groups of females and calves (Loseto 2006; Hauser et al. 2014). Excluding those two years, belugas of the contemporary era that occurred in Kotzebue Sound shared characteristics $(n=4 / 9$ haplotypes) with Beaufort Sea belugas, but also had some differences ( $n=5 / 9$ haplotypes). Of those haplotypes not found in the Beaufort Sea to date, one was recorded in Kotzebue Sound during the historical era (the pink-coloured haplotype in Fig. 5), one is common in the eastern Bering Sea and present in Bristol Bay (the brown-coloured haplotype), one was found only once in the Bering Sea (Yukon River delta) and two have not been detected elsewhere to date. This suggests the historical Kotzebue Sound stock may co-occur with whales from other stocks in Kotzebue Sound in recent times.

Traditional assignment testing and mixed-stock analyses rely on multilocus genotypes from all possible source (i.e., reference) stocks (e.g., Paetkau et al. 1995; Banks \& Eichert 2000; Pritchard et al. 2000; Pella \& Masuda 2001; Piry et al. 2004). These tests perform poorly if one or more reference stocks, such as the historical Kotzebue Sound stock, has not been adequately sampled. This limitation was partially overcome by applying exclusion tests in concert with assignment tests, which indicated that three of 85 contemporary samples had very low probabilities $(p<0.05)$ of arising in any of the known contemporary stocks. All three were sampled in July, one in 1998 and two in 2007. Our chosen exclusion criterion may be quite stringent considering the limited allelic divergence among stocks such that it is very difficult to exclude an individual from all stocks given our current resolving power. Using the more relaxed criterion of $p<0.1$, an additional three whales could not be conclusively assigned to any of the known stocks (Table 3, Supplementary Table S1); two of these were sampled in July 2007 and one in June 1996. The lack of nDNA from whales of the historical Kotzebue Sound stock prevented us from assigning the belugas with unknown stock membership to any stock, including the historical Kotzebue Sound stock.

However, we stress that the most parsimonious explanation for the current presence of an 'unknown' stock in Kotzebue Sound is that some individuals from the historic stock still exist and are harvested. Further, belugas from other stocks (especially the Beaufort Sea) are also harvested in Kotzebue Sound, at least in some years. That the historic Kotzebue Sound stock still exists is much more likely than there being an additional stock that has never been sampled before, or that a new stock emerged from interbreeding stocks. Indeed, hunters in Kotzebue Sound suspect that the large, mostly male, groups of belugas that are sometimes present in July are from someplace other than Kotzebue Sound because they do not follow the traditional movement patterns (Fig. 2). Traditionally, belugas arrived during the sea-ice break-up in late May and June (Fig. 2), and remained most of the summer, whereas the recent large groups arrive later in June or July, long after the ice has gone out, and do not appear to remain for long. Killer whales may have played a role by forcing belugas into Kotzebue Sound in recent years. The hunters also think that Kotzebue Sound belugas are still present, but in much lower numbers and for a longer duration in summer. Determining the identity of these belugas is of utmost importance and will require more sampling.

\section{What happened to belugas in Kotzebue Sound?}

The cause of the decline of belugas in Kotzebue Sound is important to consider, as it may yield some insight into why belugas have not recovered in this region. Recall that the reasons for the decline may be related to some combination of over-harvest, ice-entrapment, killer whale predation and increased disturbance by motorized hunting boats throughout the Sound, rather than just at areas where drive hunts formerly took place. We will discuss these in reverse order, from least to most likely.

Disturbance clearly increased in Kotzebue Sound when hunters transitioned from kayaks and umiaks to motorized boats; the use of outboard engines became common in the 1920s and 1930s, and by the 1940s and 1950s fewer belugas used shallow nearshore areas. However, they continued to be abundant in areas of deeper water (Foote \& Cooke 1960; Morseth 1997). Moreover, increased noise and activity have occurred throughout the range of belugas, including in Bristol Bay, Norton Sound and the Yukon River Delta in Alaska, Hudson Bay in Canada, and Anadyr Bay in Russia, yet belugas continue to frequent those areas (Caron \& Smith 1990; ABWC unpubl.).

Another reason often mentioned by hunters for the decline is a possible increase in killer whale predation. Although the presence of killer whales has increased in the Chukchi Sea recently (e.g., Stafford et al. 2018; Willoughby et al. 2020) and they are present in Kotzebue Sound (Castellote et al. 2017), the change is recent and attributed to the decline of the extent, duration and thickness of the seasonal sea ice. Until recently, sea ice in the Chukchi Sea was relatively stable compared to other places in the Arctic (e.g., Laidre et al. 2015; Huntington et al. 2020) and killer whales have always frequented the Bering Strait region (Mymrin \& Huntington 1999). In 
short, there is no evidence that the population collapse in Kotzebue Sound was due to killer whale predation.

The decline of belugas corresponded with the timing of two separate ice-entrapments near Bering Strait in 1984. The first, near Little Diomede, trapped at least 40 belugas in April of 1984 (Lowry et al. 1987), and the second in Seniavin Strait, a confined waterway between an island and the Russian mainland, trapped 2500-3000 belugas, 1000 of which perished, between December 1984 and February 1985. The entrapped belugas were a mix of ages, including 25\% two- to three-year-olds, $20 \%$ four- to six-year-olds and 55\% adults older than six years of age (Ivashin \& Shevlyagin 1987; Mymrin \& Huntington 1999). The winter range of Kotzebue Sound belugas is unknown, as is the stock identity of the entrapped belugas that perished. Although the entrapped belugas may have been from the Kotzebue Sound stock, belugas from other stocks are known to pass through this area annually (Citta et al. 2016). Additionally, the large entrapment occurred in November of 1984, months after the harvest had already declined in Kotzebue Sound (Fig. 3). The fact that these entrapments loosely co-occurred with the decline in beluga abundance in Kotzebue Sound caused local hunters to suspect that the entrapment event was why their belugas disappeared.

Although we do not know how many belugas comprised the historic Kotzebue Sound stock, it is almost certain that they were over-harvested. Various experienced observers reported seeing 900-1200 belugas in Eschscholtz Bay in 1962, 1978 and 1981, and estimated that up to 2000 may have used the area (Frost \& Lowry 1990). In the seven years between 1977 and 1983, 588 belugas were reported as landed in all of Kotzebue Sound, with no information about the number that were struck but lost (Frost \& Lowry 1990; Fig. 3). The average annual reported harvest of 84 during 19771983 would constitute $4.2 \%$ of a population of 2000 belugas each year (annual range ca. $1 \%-8 \%$ ) or $8.4 \%$ of a population of 1000 belugas (annual range ca. $1 \%$ $15 \%)$. A precautionary guideline for a safe and sustainable annual fisheries bycatch of cetaceans, referred to as the Potential Biological Removal level, is 2\% (Wade 1998). Although this was not intended to be applied to subsistence harvests by Alaska Natives, it nonetheless serves as a precautionary guideline for a sustainable harvest. The harvest clearly exceeded $2 \%$ of either estimated population size in six of seven years. Over-harvest was likely the primary cause of the population collapse in Kotzebue Sound, notwithstanding increases in disturbance and ice-entrapments. Over-harvest may also have been why harvest declined in northern Kotzebue Sound, at Sisaulik, in the 1960s and 1970s. If so, the population of belugas in Kotzebue Sound may have been declining prior to the 1980s. Indeed, IK surveys by Seaman et al. (2015) indicated that hunters noticed belugas were starting to decline in Eschscholtz Bay in the mid-1970s.

\section{Management implications}

The MMPA mandates that marine mammal population stocks be maintained as significant functioning elements of their ecosystems, requiring that each should be maintained at its optimal sustainable population level. This has been interpreted as preventing depletions across a species' range. It is clear based on the observations of local residents and scientists that lived or worked in Kotzebue Sound that belugas are much less numerous and less frequently present than they once were (Frost \& Lowry 1990; Seaman et al. 2018). In fact, there are now so few, and their annual occurrence so unpredictable, that hunters from Kotzebue no longer travel to Eschscholtz Bay to hunt belugas and it is not considered feasible to conduct aerial surveys to estimate beluga abundance.

Despite greatly reduced abundance in Kotzebue Sound, belugas continue to be harvested, albeit in low numbers in most years. Uncertainty over whether whales using the Sound today are from the greatly depleted historical-era stock or from another abundant stock has caused confusion and ambivalence among both harvesters and managers about the need to implement restrictions. The result is that the stock has not been designated as depleted under the MMPA. Without current and historical population estimates, or an adequate understanding of stock structure, there is no clear mechanism for legally defining the conservation status of Kotzebue Sound belugas and, therefore, no legal mechanism for instituting an appropriate management regime.

Our findings clarify the stock identity of belugas that regularly occurred in Kotzebue Sound prior to about 1983, but do not resolve the current conservation dilemma. The finding of at least one mtDNA haplotype unique to Kotzebue Sound in both the historical and contemporary eras suggests that remnants of this historical stock still occur and are occasionally harvested. More sampling, however, is required to further explore the existence of lineages that may be unique to Kotzebue Sound. Our results also indicate that belugas from at least one other stock, likely that of the Beaufort Sea, also occur in Kotzebue Sound, at least in some years. The most similar scenario we are aware of is beluga harvests in Nunavik, Canada. Hunters in Nunavik communities harvest belugas from three different stocks, the eastern Hudson Bay stock $(N=3400)$, the western Hudson Bay stock $(N=54$ 500) and the James Bay stock 
$(N=10600)$. Management requires that all belugas are sampled for genetic stock assignment and the proportion of the harvest attributed to each stock is assessed for each community annually and used to adjust the total allowable take in the following year, such that the total allowable take is not exceeded in any community for any stock (DFO 2018; Hammill et al. 2017; Hammill et al. 2021). The timing of harvest is also managed to redirect the harvest as much as possible away from the small eastern Hudson Bay stock and towards the much larger western Hudson Bay stock, allowing for a greater total harvest (Hammill et al. 2021). A similar management regime could be useful for Kotzebue Sound, including more genetic sampling to clarify stock structure and restricting the timing of the harvest to later in the summer, when Kotzebue belugas were traditionally less common.

In 2015, elders and beluga hunters of the Kotzebue Sound region working with the ABWC met to discuss what could be done to re-establish the former regular presence and abundance of belugas. They subsequently drafted a management plan that includes guidelines to reduce the harvest and protect the belugas, especially females with calves (Frost et al. 2021 [this special cluster]). Drafters of the Kotzebue Sound management plan acknowledged the presence of more than one stock and dealt with this by using their long-term knowledge of beluga behaviour. The plan encourages hunters not to hunt belugas from June to mid-July, when the historical stock was traditionally present. Belugas that arrive after mid-July in large groups (> 100), without grey (subadult) animals or calves, are thought to belong to another stock, and could therefore be hunted. If hunters were to abide by this provision, it could reduce the harvest of the original Kotzebue Sound stock.

Although the Kotzebue Sound management plan would help protect the remnant population, hunting of females with calves continues. Implementation of the plan is problematic because there are no specified legal consequences, so compliance is voluntary. Local subsistence hunters and leaders are faced with a dilemma; they know it is necessary to limit hunting to foster recovery because few belugas occur in summer in Kotzebue Sound. However, hunters, their families and communities around Kotzebue Sound long for belugas to be part of their diet as well as their cultural heritage and traditions. They understand that if all hunting stopped immediately, it might be decades before the stock of belugas recovers enough to support a sustainable harvest, if they recover at all. A similarly greatly depleted stock of belugas in Cook Inlet has not been hunted since 2005 (Hobbs et al. 2019) and continues to slowly decline (Shelden $\delta$ Wade 2019).
We recommend that the most pragmatic way forward is for the U.S. Government to recognize the original Kotzebue Sound population as a stock and to work through the co-management process with the ABWC and local Kotzebue Sound hunters to implement and enforce the Kotzebue Sound beluga management plan so that harvesting, especially of females with calves, is greatly reduced or eliminated in order to promote recovery or reestablishment of a healthy stock. Regardless of how it is accomplished, the US government has a legal responsibility under the MMPA to protect belugas of Kotzebue Sound, a severely depleted stock.

Further clarification of the stock identity of belugas that still utilize Kotzebue Sound will only be possible if there is additional genetic sampling. Studies using non-lethal, biopsy sampling methods (e.g., O'Corry-Crowe et al. 2015; Citta et al. 2018) are warranted. At a minimum, as long as hunting continues, every harvested beluga should be sampled for genetic analysis. Resources should also be put into supporting genetic marker development, including SNP genotyping of bone/teeth as well as soft tissue (e.g., Morin \& McCarthy 2007) and NGS approaches to further resolve historical patterns of migration and stock structure. As new analytical techniques are developed, they should also be applied to samples from Kotzebue Sound to improve our understanding of the stock structure.

Last, we note that there are benefits to implementing the management plan, even if the historic Kotzebue Sound stock does not recover. Traditional migratory patterns and the genetic characteristics of beluga stocks in the Pacific Arctic region likely reflect migratory culture that evolved over millennia (O'Corry-Crowe et al. 2018). There are no known examples of whether, or how, a stock might re-establish use of a formerly important summering area through immigration from somewhere else. By contrast, there are examples of belugas continuing to return each year to locales that have witnessed declines (e.g., Cumberland Sound, eastern Hudson Bay; COSEWIC 2004). Together, these observations suggest a tendency toward cultural conservatism in belugas that may make them particularly vulnerable to persistent local threats. Species resilience likely requires some degree of behavioural adaptability, and in the case of belugas, cultural innovation. It is possible that, if left undisturbed, belugas from other stocks migrating into Kotzebue Sound in summer, where there is largely unoccupied prime habitat for belugas, may re-establish a 'Kotzebue Sound stock.' If allowed to increase, a new population of belugas sustained by a new cultural tradition of annual return to Kotzebue Sound could help to continue that part of the rich cultural tradition of the Iñupiat that is centred around belugas in Kotzebue Sound. 


\section{Acknowledgements}

This study was a collaborative effort with the beluga hunters of Kotzebue Sound. We greatly appreciate their willingness to share their knowledge, and we thank them for collecting samples and supporting this project. Thanks also to L. Lowry, R. Schaeffer, E. Barger and B. Mahoney for their assistance. Support was also provided by Harbor Branch Oceanographic Institute at Florida Atlantic University, the Southwest Fisheries Science Center at the US National Oceanic and Atmospheric AdministrationFisheries and the North Slope Borough. All samples were collected under the authority of MMPA permits issued by the US National Marine Fisheries Service.

\section{Funding}

Financial and material support for this research was provided by the ABWC, the North Slope Borough-Shell Baseline Studies Program, the National Fish and Wildlife Foundation (project no. 2008-0105-000), Harbor Branch Oceanographic Institute at Florida Atlantic University, the Harbor Branch Oceanographic Institute Foundation, the Alaska Department of Fish and Game, the Native Village of Kotzebue and the National Marine Fisheries Service, Alaska Region.

\section{Disclosure statement}

The authors report no conflict of interest.

\section{References}

Avise J.C. 1995. Mitochondrial DNA polymorphism and a connection between genetics and demography of relevance to conservation. Conservation Biology 9, 686-690, doi: 10.1046/j.1523-1739.1995.09030686.x.

Banks M.A. \& Eichert W. 2000. WHICHRUN V4.1: a computer program for population assignment of individuals based on multilocus genotype data. Journal of Heredity 91, 88-89, doi: 10.1093/jhered/91.1.87.

Burch E.S. 1998. The Iñupiaq Eskimo nations of northwest Alaska. Fairbanks: University of Alaska Press.

Burns J.J. \& Seaman G.A. 1986. Investigations of belukha whales in coastal waters of western and northern Alaska. II: biology and ecology. Final report. Juneau, AK: Outer Continental Shelf Environmental Assessment Program.

Caron L.M.J. \& Smith T.G. 1990. Philopatry and site tenacity of belugas, Delphinapterus leucas, hunted by the Inuit at the Nastapoka estuary, eastern Hudson Bay. Canadian Bulletin of Fisheries and Aquatic Sciences 224, 69-79.

Castellote M., Stafford K. \& Small R.J. 2017. Acoustic monitoring of cetaceans in Kotzebue Sound: 2014-2017. Final report submitted to the $A B W C$, Aug 2017. Unpublished report.
Citta J.J., O'Corry-Crowe G., Quakenbush L.T., Bryan A.L., Ferrer T., Olson M.J., Hobbs R.C., \& Potgieter B. 2018. Assessing the abundance of Bristol Bay belugas with genetic mark-recapture methods. Marine Mammal Science 34, 666-686, doi: $10.1111 / \mathrm{mms} .12472$.

Citta J.J., Richard P., Lowry L.F., O'Corry-Crowe G., Marcoux M., Suydam R., Quakenbush L.T., Hobbs R.C., Litovka D.I., Frost K.J., Gray T., Orr J., Tinker B., Aderman H. \& Druckenmiller M.L. 2016. Satellite telemetry reveals population specific winter ranges of beluga whales in the Bering Sea. Marine Mammal Science 33, 236-250, doi: $10.1111 / \mathrm{mms} .12357$.

COSEWIC (Committee on the Status of Endangered Wildlife in Canada) 2004. COSEWIC assessment and update status report on the beluga whale Delphinapterus leucas in Canada. Ottawa: Committee on the Status of Endangered Wildlife in Canada.

DFO (Fisheries and Oceans Canada) 2018. Harvest advice for eastern and western Hudson Bay beluga (Delphinapterus leucas). DFO Canadian Science Advisory Secretariat Science Advisory Report 2018/008. Ottawa: Fisheries and Oceans Canada.

Excoffier L. \& Lischer H. 2015. Arlequin V3.5; an integrated software package for population genetics data analysis. Bern: University of Bern.

Fejes C. 1966. People of the Noatak. New York: Alfred A. Knopf. Foote A.C. \& Cooke D.C. 1960. The Eskimo hunter of Noatak, Alaska. Winter 1960. Summer 1960. Washington, D.C.: US Atomic Energy Commission.

Foote A.C. \& Williamson H.A. 1966. A human geographical study. In N.J. Wilimovsky \& J.N. Wolfe (eds.): Environment of the Cape Thompson region, Alaska. Pp. 1041-1107. Oak Ridge, TN: US Atomic Energy Commission.

Frost K.J., Gray T., Goodwin W. Sr., Schaeffer R. \& Suydam R. 2021. Alaska Beluga Whale Committee-a unique model of co-management. Polar Research 40, article no. 5611, doi: 10.33265/polar.v40.5611.

Frost K.J. \& Lowry L.F. 1990. Distribution, abundance, and movements of beluga whales, Delphinapterus leucas, in coastal waters of western Alaska. Canadian Bulletin of Fisheries and Aquatic Sciences 224, 39-57.

Giddings J.L. \& Anderson D.A. 1986. Beach ridge archeology of Cape Krusenstern: Eskimo and pre-Eskimo settlements around Kotzebue Sound, Alaska. Vol. 20. Washington, D.C.: National Park Service.

Hammill M.O., Mosnier A. \& Bordeleau X. 2021. An update of impacts of harvesting on the abundance of Nunavik beluga. DFO Canadian Science Advisory Secretariat Research Document 2021/003. Ottawa: Fisheries and Oceans Canada.

Hammill M.O., Mosnier A., Gosselin J.-F., Matthews C.J.D., Marcoux M. \& Ferguson S.H. 2017. Management approaches, abundance indices and total allowable harvest levels of belugas in Hudson Bay. DFO Canadian Science Advisory Secretariat Research Document 2017/062. Ottawa: Fisheries and Oceans Canada.

Hauser D.D.W., Laidre K.L., Suydam R.S. \& Richard P.R. 2014. Population-specific home ranges and migration timing of Pacific Arctic beluga whales (Delphinapterus leucas). Polar Biology 37, 1171-1183, doi: 10.1007/ s00300-014-1510-1. 
Hobbs R.C.. Reeves R.R., Prewitt J.S., Desportes G., Bretonhoneyman K., Christensen T., Citta J.J., Ferguson S.H., Frost K.J., Garde E., Gavrilo M., Ghazal M., Glazov D.M., Gosselin J.-F., Hammill M., Hansen R.G., Harwood L., Heide-Jørgensen M.P., Inglangasuk G., Kovacs K.M., Krasnova V.V., Kuznetsova D.M., Lee D.S., Lesage V., Litovka D.I., Lorenzen E.D., Lowry L.F., Lydersen C., Matthews C.J.D., Meschersky I.G., Mosnier A., O'CorryCrowe G., Postma L., Quakenbush L.T., Shpak O.V., Skovrind M., Suydam R.S. \& Watt C.A. 2019. Global review of the conservation status of monodontid stocks. Marine Fisheries Review 81(3-4), 1-53, doi: 10.7755/ MFR.81.3-4.1.

Höss M. \& Pääbo S. 1993. DNA extraction from Pleistocene bones by a silica-based purification method. Nucleic Acids Research 21, 3913-3914, doi: 10.1093/nar/21.16.3913.

Huntington H.P. \& the communities of Buckland, Koyuk, Shaktoolik and Point Lay 1999. Traditional knowledge of the ecology of beluga whales (Delphinapterus leucas) in the eastern Chukchi and Northern Bering Seas, Alaska. Arctic 52, 49-61, doi: 10.14430/arctic909.

Huntington H.P., Danielson S.L., Wiese F.K., Baker M., Boveng P., Citta J.J., De Robertis A., Dickson D.M.S., Farley E., George J.C., Iken K., Kimmel D.G., Kuletz K., Ladd C., Levine R., Quakenbush, L., Stabeno P., Stafford K.M., Stockwell D. \& Wilson, C. 2020. Evidence suggests potential transformation of the Pacific Arctic ecosystem is underway. Nature Climate Change 10, 242-248, doi: 10.1038/s41558-020-0695-2.

Ivashin M.V. \& Shevlyagin K.V. 1987. The white whale (Delphinapterus leucas Pallas, 1776): entrapment and escape in the ice of Senjavin Strait, U.S.S.R. Reports of the International Whaling Commission 37, 357-359.

Laidre K.L., Stern H., Kovacs K.M., Lowry L., Moore S.E., Regehr E.V., Ferguson S.H., Wiig O., Boveng P., Angliss R.P., Born E.W., Litovka D., Quakenbush L., Lydersen C., Vongraven D. \& Ugarte F. 2015. Arctic marine mammal population status, sea ice habitat loss, and conservation recommendations for the 21 st century. Conservation Biology 29, 724-737, doi: 10.1111/cobi.12474.

Loseto L.L., Richard P., Stern G.A., Orr J. \& Ferguson S.H. 2006. Segregation of Beaufort Sea beluga whales during the open-water season. Canadian Journal of Zoology 84, 1743-1751, doi: 10.1139/Z06-160.

Lowry L.F., Burns J.J. \& Nelson R.R. 1987. Polar bear predation on beluga whales in the Bering and Chukchi seas. Canadian Field-Naturalist 101, 141-146.

Lowry L.F., Citta J.J., O'Corry-Crowe G., Quakenbush L.T., Frost K.J., Suydam R. \& Hobbs R.C. 2019. Distribution, abundance, harvest, and status of western Alaska beluga whale, Delphinapterus leucas, stocks. Marine Fisheries Review 81, 54-71, doi: 10.7755/MFR.81.3-4.2.

Lucier C.V. \& Vanstone J.W. 1995. Traditional beluga drives of the Iñupiat of Kotzebue Sound, Alaska. Chicago: Field Museum of Natural History.

Luque S.P. \& Ferguson S.H. 2010. Age structure, growth, mortality, and density of belugas (Delphinapterus leucas) in the Canadian Arctic: responses to environment? Polar Biology 33, 163-178, doi: 10.1007/s00300-009-0694-2.

Meschersky I.G., Shpak O.V., Litovka D.I., Glazov D.M., Borisova E.A. \& Rozhnov V.V. 2013. A genetic analysis of the beluga whale Delphinapterus leucas (Cetacea: Monodontidae) from summer aggregations in the Russian Far East. Russian Journal of Marine Biology 39, 125-135, doi: 10.1134/S1063074013020065.

Morin P.A. \& McCarthy M. 2007. Highly accurate SNP genotyping from historical and low-quality samples. Molecular Ecology Notes 7, 937-946, doi: 10.1111/j.1471-8286.2007.01804.x.

Morseth C.M. 1997. Twentieth-century changes in beluga whale hunting and butchering by the Kanjigmiut of Buckland, Alaska. Arctic 50, 241-255, doi: 10.14430/ arcticl 106.

Mymrin N.I. \& Huntington H.P. 1999. Traditional knowledge of the ecology of beluga whales (Delphinapterus leucas) in the northern Bering Sea, Chukotka, Russia. Arctic 52, 62-70.

NMFS (National Marine Fisheries Service) 2005. Revisions to guidelines for assessing marine mammal stocks. Accessed on the internet at https://www.fisheries.noaa.gov/national/marine-mammal-protection/ guidelines-assessing-marine-mammal-stocks\#previous-workshop-reports-and-guidelines on 17 September 2021.

O'Corry-Crowe G.M., Dizon A.E., Suydam R.S. \& Lowry L.F. 2002. Molecular genetic studies of population structure and movement patterns in a migratory species: the beluga whale (Delphinapterus leucas) in the western Nearctic. In C.J. Pfeiffer (ed.): Molecular and cell biology of marine mammals. Pp. 53-64. Malabar, FL: Krieger Publishing Co.

O'Corry-Crowe G., Lucey W., Archer F.I. \& Mahoney B. 2015. The genetic ecology and population origins of the beluga whales of Yakutat Bay. Marine Fisheries Review 71, 47-48, doi: 10.7755/MFR.77.1.5.

O'Corry-Crowe G.M., Lydersen C., Heide-Jørgensen M.P., Hansen L., Mukhametov L.M., Dove O., Kovacs K.M. 2010. Population genetic structure and evolutionary history of North Atlantic beluga whales (Delphinapterus leucas) from west Greenland, Svalbard and the White Sea. Polar Biology 33, 1179-1 194, doi: 10.1007/s00300-010-0807-y.

O'Corry-Crowe G., Mahoney A., Suydam R., Quakenbush L., Whiting A., Lowry L. \& Harwood L. 2016. Genetic profiling links changing sea ice to shifting beluga whale migration patterns. Biology Letters 12, article no. 20160404, doi: 10.1098/rsbl.2016.0404.

O'Corry-Crowe G., Suydam R., Quakenbush L., Potgieter B., Harwood L., Litovka D., Ferrer T., Citta J., Burkanov V., Frost K. \& Mahoney B. 2018. Migratory culture, population structure and stock identity in North Pacific beluga whales (Delphinapterus leucas). PLoS One 13, e0194201, doi: 10.1371/journal.pone.0194201.

O'Corry-Crowe G.M., Suydam R.S., Rosenberg A., Frost K.J. \& Dizon A.E. 1997. Phylogeography, population structure and dispersal patterns of the beluga whale Delphinapterus leucas in the western Nearctic revealed by 
mitochondrial DNA. Molecular Ecology 6, 955-970, doi: 10.1046/j.1365-294X.1997.00267.x.

Paetkau D., Calvert W., Stirling I. \& Strobeck C. 1995. Microsatellite analysis of population structure in Canadian polar bears. Molecular Ecology 4, 347-354, doi: 10.1111/j.1365-294X.1995.tb00227.x.

Paetkau D., Slade R., Burden M. \& Estoup A. 2004. Direct, real-time estimation of migration rate using assignment methods: a simulation-based exploration of accuracy and power. Molecular Ecology 13, 55-65, doi: 10.1046/j.1365-294X.2004.02008.x.

Pella J. \& Masuda M. 2001. Bayesian methods for analysis of stock mixtures from genetic characters. Fisheries Bulletin 99, 151-167.

Piry S., Alapetite A., Cornuet J.-M., Paetkau D., Baudouin L. \& Estoup A. 2004. GeneClass2: a software for genetic assignment and first-generation migrant detection. Journal of Heredity 95, 536-539, doi: 10.1093/jhered/esh074.

Pritchard J.K., Stephen M. \& Donnelly P. 2000. Inference of population structure using multilocus genotype data. Genetics 155, 945-959.

Richard P.R., Martin A.R. \& Orr J.R. 2001. Summer and autumn movements of belugas of the eastern Beaufort Sea stock. Arctic 54, 223-236, doi: 10.14430/arctic783.

Rohland N. \& Hofreiter M. 2007. Ancient DNA extraction from bones and teeth. Nature Protocols 2, 1756-1762.

Seaman G.A., Barger E. \& Raymond L. Jr. 2015. Buckland Beluga Whale Traditional Ecological Knowledge Project. Final report. Buckland, AK: Buckland Beluga Traditional Ecological Knowledge Project.

Seaman G.A., Frost K.J. \& Lowry L.F. 1986. Investigations of belukha whales in coastal waters of western and northern Alaska. I. Distribution, abundance, and movements. Final report. Outer Continental Shelf Environmental Assessment Program. Anchorage: National Oceanic and Atmospheric Administration.
Seaman G.A. \& Noatak IRA Council 2018. Noatak Beluga Whale Traditional Knowledge Project. Final report. Noatak, AK: Native Village of Noatak.

Shelden K.E.W. \& Wade P.R. (eds.) 2019. Aerial surveys, distribution, abundance, and trend of belugas (Delphinapterus leucas) in Cook Inlet, Alaska, June 2018. AFSC Processed Report 2019-09. Seattle: Alaska Fisheries Science Center, National Marine Fisheries Service National Oceanic and Atmospheric Administration, US Dept. of Commerce.

Stafford K.M. 2019. Increasing detections of killer whales (Orcinus orca) in the Pacific Arctic. Marine Mammal Science 35: 696-706, doi: 10.1111/mms.12551.

van Oosterhout C., Hutchinson W.F., Wills D.P.M. \& Shipley P. 2004. MICRO-CHECKER: software for identifying and correcting genotyping errors in microsatellite data. Molecular Ecology Notes 4, 535-538, doi: 10.1111/j.1471-8286.2004.00684.x.

Wade P.R. 1998. Calculating limits to the allowable human caused mortality of cetaceans and pinnipeds. Marine Mammal Science 14, 1-37, doi: 10.1111/j.1748-7692.1998.tb00688.x.

Wade P.R. \& Angliss R. 1997. Guidelines for assessing marine mammal stocks: report of the GAMMS workshop. April 3-5, 1996, Seattle, Washington. NOAA Technical Memorandum NMFS-OPR-12. Silver Spring, MD: National Atmospheric and Oceanic Administration.

Whiting A., Castellote M., Small R.J., Frost K.J. \& Suydam R. 2019. Unexpected mid-winter presence of harbor porpoises (Phocoena phocoena) in Kotzebue Sound, Alaska. Marine Mammal Science 36, 354-358, doi: 10.1111/mms.12641.

Willoughby A.L., Ferguson M.C., Stimmelmayr R., Clarke J.T. \& Brower A.A. 2020. Bowhead whale (Balaena mysticetus) and killer whale (Orcinus orca) co-occurrence in the U.S. Pacific Arctic, 2009-2018: evidence from bowhead whale carcasses. Polar Biology 43, 1669-1679, doi: 10.1007/s00300-020-02734-y. 